\title{
Chemical Control of Coffee Nematodes in Seedbeds in Puerto Rico ${ }^{1,2}$
}

\author{
Rodrigo Echávez Badel and Alejandro Ayala ${ }^{3}$
}

\begin{abstract}
Pre-plant soil treatments with granular formulations and foliar sprays with the nematicides phenamiphos (Nemacur), oxamyl, (Vydate) and fensulfothion (Dasanit) reduced populations of Meloidogyne incognita and Pratylenchus coffeae in coffee ( Coffea arabica L.) cv. Puerto Rico Selecto roots. Significant $(P=0.05)$ increases in growth and development of the treated plants were obtained in the greenhouse. Best results were obtained with $11.20 \mathrm{~kg}$ ai/ha of phenamiphos applied to the soil 15 days prior to planting, combined with foliar sprays of $1.12 \mathrm{~kg}$ ai/ha of the same systemic nematicide 15 days after transplanting or two foliar sprays with $0.56 \mathrm{~kg}$ ai/ ha applied at intervals of 30 days; $0.56 \mathrm{~kg}$ ai/ha of oxamyl applied to the foliage 30 and 60 days after transplanting; and 4 granular soil applications of $300 \mathrm{mg}$ of fensulfothion at 30-day intervals. Dipping roots in a solution containing $400 \mathrm{p} / \mathrm{m}$ of phenamiphos and $600 \mathrm{p} / \mathrm{m}$ of oxamyl also reduced nematode populations in roots and soil. Significant differences in root-knot index were found among those treatments and the controls, but plant growth was not affected. The higher dosages $(2.24 \mathrm{~kg}$ ai/ha) of phenamiphos and fensulfothion when applied to the leaves twice after transplanting were phytotoxic to the coffee seedlings resulting in early defoliation, but not killing the plants.
\end{abstract}

\section{IN'TRODUCTION}

In Puerto Rico 52,000 ha are cultivated in coffee, producing 11,428 $t$ of shelled coffee (5). Coffee production is limited by a number of factors, among which the attack by phytopathogenic nematodes is one of the most important. Many plantings in Puerto Rico are only marginally profitable because intensive cultivation practices are not employed (20). Fundamental to more intensive cultivation of coffee is the production of seedlings free of nematodes. Nematodes that could be controlled at the seedbed level may not be controlled when widely dispersed in the plantation. Even if possible, plantationwide control of phytopathogenic nematodes may be prohibitively expensive (14). This is a report of studies on the control of phytopathogenic nematodes in coffee seedbeds by various chemical treatments.

\section{MATERIALS AND METHODS}

The research was conducted in greenhouses at the University of Puerto Rico, Mayagüez Campus. Coffee cv. Puerto Rico Selecto was sown in an

\footnotetext{
${ }^{1}$ Manuscript submitted to Editorial Board September 21, 1979.

${ }^{2}$ Paper submitted as partial fulfillment of the requirements for the degree of Master of Science, Mayagüez Campus, University of Puerto Rico, Mayagüez, P.R.

${ }^{3}$ Research Assistant and Nematologist, respectively, Crops Protection Department, College of Agricultural Sciences, Mayagüez Campus, University of Puerto Rico, Mayagüez, P.R. 00708.
} 
Ultisol-cachaza (1:1) mixture $(\mathrm{pH} 7.2)$ and grown in the greenhouse (air temperature $25-40^{\circ} \mathrm{C}$ and soil temperature $23-40^{\circ} \mathrm{C}$ ).

Nematodes (Meloidogyne incognita, Pratylenchus coffeae, and Rotylenchulus reniformis) were isolated from infected coffee plants in the field and increased in coffee seedlings grown in the above-mentioned soil mixture in polyethylene bags. Test plants at the seedling stage (cotyledons fully expanded) were inoculated by being transplanted into the bags where nematodes were increased.

The nematode population levels were determined by using $100 \mathrm{~cm}^{3}$ soil samples taken before nematicide application, 1 month afterwards, and at the end of the experiment. Root samples ( 1 and $5 \mathrm{~g}$ ) were taken at the end of the experiment. Nematodes were extracted by the Baermann funnel technique and Cobb's sieving method (9).

A randomized complete block design was used in all tests. The following parameters were evaluated at the 8- to 9-month stage: plant height, root length, number of leaves and branches, fresh and dry weights of foliage and roots. Root-knot index (0-5 Sasser scale), necrosis index (0-5 standard scale) and nematode populations were also evaluated.

Granular phenamiphos (Nemacur 15G, 35L), ${ }^{4}$ carbofuran (Furadan 5G, 40.64 EG), fensulfothion (Dasanit 15G, 63.5 L) and oxamyl (Vydate $10 \mathrm{G}$, $24 \mathrm{~L}$ ) were applied to the soil at the rates of 75,150 and $300 \mathrm{mg}$ of the commercial product per plant. Applications were made four times every 30 days, starting when the plants were 3 months old. Each treatment was replicated four times.

Emulsifiable concentrates of the same chemicals were also evaluated by spraying the foliage twice at 30-day intervals after transplanting, using $0.56,1.12$ and $2.24 \mathrm{~kg}$ ai/ha. These treatments were replicated five times.

Granular phenamiphos containing 11.2 and $22.4 \mathrm{~kg}$ ai/ha were applied to the soil 15 days before transplanting, followed by either one or two foliar applications at 0 and/or $1.12 \mathrm{~kg}$ ai/ha; 15 and 45 days after transplanting. The same method of application was used with granular (22.4 and $44.8 \mathrm{~kg}$ ai/ha) and sprayed (0 and/or $1.12 \mathrm{~kg}$ ai/ha) oxamyl. These treatments were replicated four times.

Three dosages $(0,11.2$ and $22.4 \mathrm{~kg}$ ai/ha) of phenamiphos were incorporated into the soil 15 days prior to transplanting, followed by foliar sprays with the same chemical at $0,0.56,1.12$, and $2.24 \mathrm{~kg}$ ai/ha every 30 days. The first foliar application was made 1 month after the pre-transplant soil treatment. Treatments were replicated five times.

The roots of coffee seedlings (60 days old) were immersed for 5 and 10

\footnotetext{
${ }^{4}$ Trade names in this publication are used only to provide specific information. Mention of a trade name does not constitute a warranty of equipment of material by the Agricultural Experiment Station of the University of Puerto Rico, nor is this mention a statement of preference over other equipment or materials.
} 
min in solutions of phenamiphos containing 200,400 and $800 \mathrm{p} / \mathrm{m}$. The same method was used with oxamyl at $600,1,200$, and $2,400 \mathrm{p} / \mathrm{m}$. The check plants' roots were immersed in distilled water for the same period of time. All treatments were replicated five times.

\section{RESULTS AND DISCUSSION}

\section{FREQUENCY OF PRETRANSPLANT APPLICATIONS USING GRANULAR AND SPRAY FORMULATIONS}

In general, granular nematicides improved growth and development of coffee seedlings; this was especially true with fensulfothion at the rate of $300 \mathrm{mg}$ of the commerical product per plant (table 1), which significantly increased the number of leaves over the controls. Similar results were

TABLE 1.-Effect of post-transplant applications of granular nematicides on the growth and development of Coffee Coffea arabica L. cu. Puerto Rico Selecto) seedlings

\begin{tabular}{|c|c|c|c|c|c|}
\hline \multicolumn{2}{|c|}{ Treatment $^{1}$} & \multirow{2}{*}{ Leaves } & \multirow{2}{*}{$\begin{array}{l}\text { Foliar dry } \\
\text { weights }\end{array}$} & \multicolumn{2}{|c|}{ Root weight } \\
\hline Nematicide & $\begin{array}{c}\text { Dosis } \\
\mathrm{mg} / \text { plant }\end{array}$ & & & Fresh & Dry \\
\hline & & No. & $g$ & $g$ & $g$ \\
\hline Fensulfothion & 300 & $69.50 \mathrm{a}^{2}$ & $22.32 \mathrm{a}$ & $46.87 \mathrm{a}$ & $6.55 \mathrm{ab}$ \\
\hline Phenamiphos & 300 & $56.25 \mathrm{ab}$ & $17.75 \mathrm{ab}$ & $33.92 a b$ & $4.60 a b$ \\
\hline Carbofuran & 300 & $54.00 \mathrm{ab}$ & $18.15 \mathrm{ab}$ & $35.67 \mathrm{ab}$ & $5.23 a b$ \\
\hline Oxamyl & 300 & $45.25 \mathrm{ab}$ & $16.95 \mathrm{ab}$ & $16.95 \mathrm{ab}$ & $4.30 \mathrm{ab}$ \\
\hline $\begin{array}{l}\text { Control } \\
\quad \text { (No treatment) }\end{array}$ & - & $32.50 \mathrm{~b}$ & $11.27 \mathrm{~b}$ & $22.02 \mathrm{ab}$ & $3.05 \mathrm{~b}$ \\
\hline
\end{tabular}

\footnotetext{
${ }^{1}$ Plants were treated $1,2,3$, and 4 months after transplanting.

${ }^{2}$ Means in the same column followed by the same letters do not differ significantly at the .05 level by Duncan's new Multiple Range Test.
}

obtained by Abrego $(1,2)$ and Monterroso (17). Bee (7) and Roman et al. (19) reported that multiple doses of fensulfothion improved yields of sorghum and bananas, respectively.

Foliar applications with $.56 \mathrm{~kg}$ ai/ha (lower doses) of oxamyl, 1 and 2 months after transplanting also improved the growth and development of coffee seedlings; foliar fresh weights and plant height were greater than those of the checks. Phenamiphos increased plant height and was significantly better also than the controls and fensulfothion (table 2). The higher dosis (2.24 kg ai/ha) caused phytotoxicity. Abrego and Cardona (4), and Monterroso (17) recommended oxamyl and phenamiphos for the control of parasitic nematodes on coffee seedbeds. Ayala et al. (16) and Hanania (12) reported that the higher dosages of phenamiphos and oxamyl were phytotoxic to papaya and soybean, respectively. 
PRE-TRANSPLANT AND FOLIAR APPLICATIONS OF PHENAMIPHOS AND

OXAMYL

Table 3 illustrates the results of a second greenhouse experiment to determine the frequency of application for phenamiphos and oxamyl. Granular phenamiphos at $11.2 \mathrm{~kg}$ ai/ha, applied to the soil 15 days prior

TABLE 2.-Effect of foliar applications with four nematicides on the growth and development of coffee Coffea arabica L. cv. Puerto Rico Selecto) seedlings

\begin{tabular}{|c|c|c|c|c|c|}
\hline \multicolumn{2}{|c|}{ Treatment $^{1}$} & \multicolumn{2}{|c|}{ Weight of foliage } & \multirow{2}{*}{$\begin{array}{l}\text { Root dry } \\
\text { weight }\end{array}$} & \multirow{2}{*}{ Plant height } \\
\hline Nematicide & Dosis & Fresh & Dry & & \\
\hline & (Kg ai/ha) & $g$ & $g$ & $g$ & $\mathrm{~cm}$ \\
\hline Oxamyl & 0.56 & $24.92 \mathrm{a}^{2}$ & $7.78 \mathrm{a}$ & $2.38 \mathrm{a}$ & $26.20 \mathrm{ab}$ \\
\hline Phenamiphos & 0.56 & $21.38 \mathrm{ab}$ & $6.60 \mathrm{ab}$ & $1.46 \mathrm{ab}$ & $27.20 \mathrm{a}$ \\
\hline Carbofuran & 0.56 & $19.62 a b$ & $5.88 \mathrm{ab}$ & $1.28 \mathrm{ab}$ & $23.50 \mathrm{abc}$ \\
\hline Fensulfothion & 0.56 & $19.06 \mathrm{ab}$ & $6.00 \mathrm{ab}$ & $1.32 \mathrm{~b}$ & $19.60 \mathrm{bcd}$ \\
\hline $\begin{array}{l}\text { Control } \\
\text { (No treatment) }\end{array}$ & - & $16.04 \mathrm{~b}$ & $5.52 \mathrm{ab}$ & $1.64 \mathrm{ab}$ & 11.40 \\
\hline
\end{tabular}

'Nematicides were foliarly applied 1 and 2 months after transplanting the coffee seedlings.

${ }^{2}$ Means in the same column followed by the same letters do not differ significantly at the .05 level by Duncan's new Multiple Range Test.

TAB̊LE 3.-Effect of pre-and post-transplant applications of phenamiphos and oxamyl on the development and growth of coffee (cv. Puerto Rico Selecto) seedlings

\begin{tabular}{|c|c|c|c|c|c|c|}
\hline \multirow[b]{2}{*}{ Nematicide } & \multicolumn{2}{|c|}{ Dose } & \multirow[b]{2}{*}{ Plant height } & \multirow[b]{2}{*}{ Leaves } & \multicolumn{2}{|c|}{ Weight of foliage } \\
\hline & $\begin{array}{c}\text { Pre- } \\
\text { transplant }\end{array}$ & $\begin{array}{l}\text { Post- } \\
\text { transplant }\end{array}$ & & & Fresh & Dry \\
\hline & \multicolumn{2}{|c|}{ Kg ai/ha } & $\mathrm{cm}$ & No. & $g$ & $g$ \\
\hline Phenamiphos & 11.2 & 1.12 & $35.62 \mathrm{a}^{3}$ & $14.00 \mathrm{a}$ & $24.90 \mathrm{a}$ & $7.63 \mathrm{a}$ \\
\hline Oxamyl & 22.4 & 1.12 & $20.62 \mathrm{bc}$ & $9.00 \mathrm{ab}$ & $13.42 \mathrm{~b}$ & $3.78 \mathrm{~b}$ \\
\hline Oxamyl & 22.4 & $1.12,1.12$ & $18.25 \mathrm{bc}$ & $10.00 \mathrm{ab}$ & $12.82 \mathrm{~b}$ & $3.70 \mathrm{~b}$ \\
\hline Phenamiphos & 11.2 & $1.12,1.12$ & $16.37 \mathrm{c}$ & $8.50 \mathrm{~b}$ & $10.70 \mathrm{~b}$ & $3.05 \mathrm{~b}$ \\
\hline Controls & - & - & $15.70 \mathrm{c}$ & $10.50 \mathrm{ab}$ & $17.60 \mathrm{ab}$ & $5.15 \mathrm{ab}$ \\
\hline
\end{tabular}

${ }^{1}$ Granular application 15 days before transplanting.

${ }^{2}$ Two foliar applications; the first, 15 days after transplanting, and the second, 1 month later.

${ }^{3}$ Means in the same column followed by the same letters do not differ significantly at the 0.5 level by Duncan's new multiple range test.

to transplanting and followed by one foliar spray $(1.12 \mathrm{~kg}$ ai $/ \mathrm{ha})$ increased plant height over the remaining treatments, including the controls. Abrego (3), Abrego and Cardona (4), and Gómez (11) reported similar results with combinations of granular and foliar sprays of phenamiphos on coffee seedbeds. The best time for the application of this nematicide seemed to be 15 days before and after transplanting. 


\section{GRANULAR AND LIQUID FORMULATIONS OF PHENAMIPHOS}

Results demonstrated that one application of $11.2 \mathrm{~kg} / \mathrm{ha}$ of granular phenamiphos incorporated into the soil 15 days prior to transplanting, followed by two foliar applications $(0.56 \mathrm{~kg} / \mathrm{ha}) 15$ and 45 days afterwards improved growth and development of coffee seedlings. Good control of phytoparasitic nematodes was obtained (table 4). Abrego (3), using lower and multiple dosages of phenamiphos, effectively controlled coffee nematodes at El Salvador. Higher doses of the chemical adversely affected the coffee seedlings; phytotoxicity symptoms were developed during the first 4 months after transplanting. Similar phytotoxicity symptoms were

TABLE 4.-Fluctuations of nematode populations and coffee plant growth after applying phenamiphos 15 days prior to transplanting and followed by two foliar applications 15 and 45 days afterwards

\begin{tabular}{|c|c|c|c|c|c|c|c|c|}
\hline \multirow{3}{*}{ Nematicide } & \multicolumn{2}{|c|}{ Dose } & \multicolumn{4}{|c|}{ Nematode populations } & \multicolumn{2}{|c|}{ Plant growth } \\
\hline & \multirow{2}{*}{$\begin{array}{c}\text { Pre- } \\
\text { trans- } \\
\text { plant }\end{array}$} & \multirow{2}{*}{$\begin{array}{l}\text { Post- } \\
\text { transplant }\end{array}$} & \multicolumn{3}{|c|}{$\begin{array}{l}\text { Soil sampling se- } \\
\text { quence }\left(100 \mathrm{~cm}^{3}\right)^{1}\end{array}$} & \multirow{2}{*}{$\begin{array}{l}\text { Har- } \\
\text { vest- } \\
\text { ed } \\
\text { root } \\
(1 \mathrm{~g})\end{array}$} & \multirow{2}{*}{ Height } & \multirow{2}{*}{$\begin{array}{l}\text { Root } \\
\text { length }\end{array}$} \\
\hline & & & 0 & 1 & 2 & & & \\
\hline & \multicolumn{2}{|c|}{ Kg ai/ha } & & & & & $\mathrm{cm}$ & $\mathrm{cm}$ \\
\hline Phenamiphos & 11.2 & $0.56,0.56$ & 80 & 52 & 16 & 20 & $20.90 \mathrm{a}^{2}$ & $13.80 \mathrm{a}$ \\
\hline Phenamiphos & 11.2 & $2.24,2.24$ & 64 & 64 & 0 & 5 & $18.70 \mathrm{ab}$ & $8.50 \mathrm{~d}$ \\
\hline Phenamiphos & 11.2 & $1.12,1.12$ & 80 & 76 & 0 & 6 & $17.72 \mathrm{abc}$ & $13.30 \mathrm{ab}$ \\
\hline Control & - & - & 32 & 32 & 48 & 80 & $9.80 \mathrm{c}$ & $9.50 \mathrm{bcd}$ \\
\hline
\end{tabular}

${ }^{1} 0=$ Application prior to transplanting; $1=1$ month after; $2=$ end of the experiment.

${ }^{2}$ Means in the same column followed by the same letters do not differ significantly at the .05 level by Duncan's new multiple range test.

TABLE 5.-Nematodes recovery from $100 \mathrm{~cm}^{3}$ of soil and $1 \mathrm{~g}$ of roots, nodulation and necrosis indexes when coffee root systems were immersed in solutions of two systemic nematicides

\begin{tabular}{|c|c|c|c|c|c|c|c|}
\hline \multirow{2}{*}{\multicolumn{2}{|c|}{ Treatment }} & \multirow{3}{*}{$\begin{array}{l}\text { Immersion } \\
\text { time }\end{array}$} & \multirow{2}{*}{\multicolumn{2}{|c|}{$\begin{array}{c}\text { Nematode populations } \\
\text { Soil sampling sequence } \\
(100 \mathrm{cc})\end{array}$}} & \multirow{3}{*}{ Roots (g) } & \multirow{2}{*}{\multicolumn{2}{|c|}{ Index ${ }^{3}$}} \\
\hline & & & & & & & \\
\hline \multirow[t]{2}{*}{ Nematicide } & Dose & & Before $^{1}$ & After $^{2}$ & & Nodulation & Necrosis \\
\hline & $p / m$ & $\min$ & & & & & \\
\hline Phenamiphos & 400 & 10 & 504 & 20 & 16 & $0.25 \mathrm{c}^{4}$ & $0.25 \mathrm{~b}$ \\
\hline Phenamiphos & 600 & 10 & 800 & 80 & 12 & $0.25 \mathrm{c}$ & $1.50 \mathrm{ab}$ \\
\hline Oxamyl & 1200 & 10 & 740 & 40 & 80 & $1.25 \mathrm{bc}$ & $1.75 \mathrm{ab}$ \\
\hline Phenamiphos & 200 & 10 & 720 & 60 & 52 & $1.50 \mathrm{bc}$ & $0.25 \mathrm{~b}$ \\
\hline Controls & - & - & 790 & 1540 & 164 & $3.5 \mathrm{a}$ & $2.00 \mathrm{ab}$ \\
\hline
\end{tabular}

${ }^{1}$ Nematode populations before treating with nematicides.

${ }^{2}$ Nematode populations at the end of the experiment.

${ }^{3}$ Nodulation index: 0 (no nodules) to 5 (more than 100 nodules). Necrosis index: 0 (no necrosis) to 5 (very severe necrosis).

${ }^{4}$ Means in the same column followed by the same letters do not differ significantly at the .05 level by Duncan's new multiple range test. 
observed by Ayala et al. (6), Inserra et al. (13) and Pessoa (18) with higher doses of phenamiphos in papaya, gardenia and bananas, respectively.

\section{ROOT DIPS USING OXAMYL AND PHENAMIPHOS}

Coffee roots immersed for $10 \mathrm{~min}$ in solutions of $400 \mathrm{p} / \mathrm{m}$ of phenamiphos and $600 \mathrm{p} / \mathrm{m}$ of oxamyl had a lower galling index than those of the controls and fewer endoparasitic nematodes in the soil (tables 5, 6). Miller (15) reported that a solution containing $400 \mathrm{p} / \mathrm{m}$ of phenamiphos effectively controlled root knot nematodes in gardenia roots.

In general, the results indicated that at the end of the experiments nematode populations were lower in soil treated with nematicides than in the controls. Populations of $P$. coffeae recovered from the soil and coffee roots were lower than those of $M$. incognita. This may have been

TABLE 6.-Fluctuations of phytoparasitic nematode populations in $100 \mathrm{~cm}^{3}$ of soil and 1 $g$ of roots from coffee root system immersed in solutions of two nematicides

\begin{tabular}{|c|c|c|c|c|c|c|c|c|c|c|}
\hline \multicolumn{2}{|c|}{ Treatment } & \multirow{3}{*}{$\begin{array}{c}\text { Immersion } \\
\text { time }\end{array}$} & \multicolumn{4}{|c|}{ M. incognita } & \multicolumn{4}{|c|}{ P. coffeae } \\
\hline \multirow{2}{*}{ Nematicide } & \multirow{2}{*}{ Dosis } & & \multicolumn{3}{|c|}{ Soil Sampling ${ }^{1}$} & \multirow{2}{*}{ Roots } & \multicolumn{3}{|c|}{ Soil Sampling } & \multirow{2}{*}{ Roots } \\
\hline & & & 0 & 1 & 2 & & 0 & 1 & 2 & \\
\hline & $p / m$ & $\min$ & & & & & & & & \\
\hline Phenamiphos & 200 & 10 & 300 & 154 & 15 & 40 & 50 & 46 & 10 & 12 \\
\hline Phenamiphos & 400 & 10 & 208 & 100 & 10 & 10 & 40 & 20 & 0 & 6 \\
\hline Oxamyl & 600 & 10 & 200 & 50 & 20 & 4 & 180 & 50 & 20 & 8 \\
\hline Oxamyl & 1200 & 10 & 200 & 104 & 10 & 60 & 160 & 102 & 10 & 20 \\
\hline Control & - & 10 & 200 & 255 & 490 & 112 & 191 & 253 & 280 & 52 \\
\hline
\end{tabular}

${ }^{1}$ Soil sampling sequence: $0=$ before root immersion; $1=$ one month after; and $2=$ at the end of the experiment.

due to the high temperatures prevailing during the experiments, which reduced the reproductive potential or the pathogenic capabilities of $P$. coffeae. According to Miller and Rich (16) populations of the lesion nematode in soil decreased when temperatures were high $\left(10-30^{\circ} \mathrm{C}\right)$. Chapman and Turner (8) suggested that root knot nematode populations affect the population levels of the lesion nematode when attacking the same host. The life cycle of the root knot nematode (20-30 days) is shorter than that of the lesion nematode (50-60 days); the root knot nematode is more prolific (1500 vs. 10 eggs) and has an efficient reproductive system (parthenogenesis vs. amphimixis of lesion nematode).

\section{RESUMEN}

Formulaciones granuladas de phenamiphos (Nemacur), oxamyl (Vydate) y fensulfothion (Dasanit) aplicadas al suelo y emulsiones concen- 
tradas al follaje mantuvieron bajas las densidades poblacionales de Meloidogyne incognita y Pratylenchus coffeae, incrementando significativamente (P:0.05) en el invernadero el desarrollo y crecimiento de plántulas de café, cultivar Puerto Rico selecto. Los mejores resultados se obtuvieron con los siguientes tratamientos: phenamiphos a razón de $11.20 \mathrm{~kg} \mathrm{ia} / \mathrm{ha}$ aplicado al suelo 15 días antes del transplante, combinado con una aspersión al follaje de $1.12 \mathrm{~kg}$ ia/ha 15 días después del transplante o con dos aspersiones de $0.56 \mathrm{~kg}$ ia/ha al follaje 30 y 60 días después del transplante; dos aspersiones de oxamyl (0.56 kg ia/ ha) a intervalos de 30 días y fensulfothion granulado a razón de $300 \mathrm{mg}$ del material comercial por planta en cuatro aplicaciones a intervalos de 30 días, comenzando un mes y terminando 7 meses después del transplante. La inmersión de las raíces de café durante 10 minutos en una solución de 400 ppm de phenamiphos y 600 ppm de oxamyl, respectivamente, redujeron los niveles poblacionales de los nematodos noduladores y lesionadores en el suelo y en las raíces. Aunque se encontraron diferencias significativas ( $P: 0.05$ ) en el índice de nodulación entre estos tratamientos y el testigo, el incremento en el desarrollo y crecimiento de las plantas no fue significativo. Dosificaciones altas de phenamiphos y fensulfothion (2.24 kg ia/ha) asperjadas más de una vez al follaje después del transplante causaron fitotoxicidad y defoliación parcial durante los primeros meses del crecimiento, pero sin ocasionar la muerte de las plantas.

\section{LITERATURE CITED}

1. Abrego, L., 1963. Progresos en el control de nematodos en almacigueros de café. Inst. Salvadoreño Invest. Café. Bol. No. 51: 1-6.

2. - 1971. Los nematodos, un problema del café en El Salvador, Nematropica 1(1): 19. (Abstr.)

3. - 1975. Contribuciones a la investigación nematológica en el cultivo del cafeto, Inst. Salvadoren̄o Invest. Café. Mimeógráfo, p. 11-15.

4. - - y Cardona, L. M., 1976. Ensayos de selectividad de nematicidas en el combate de nemátodos (Pratylenchus coffeae) en almacigueros de café, Rev. Cafetalera Guatem., p. 17-20.

5. Anónimo. Anuario de estadísticas agrícolas de Puerto Rico 1975-76. Oficina de Estadísticas y Estudios. Estado Libre Asociado de P.R., Departamento de Agricultura, Santurce, P. R.

6. Ayala, A., Acosta, N. y Adsuar, J. A., 1971. Informe preliminar sobre la respuesta de Carica papaya a aplicaciones foliares de dos nematicidas sistémicos, Nematropica 1(1): 29-30.

7. Bee, D., 1974. Estudio sobre una enfermedad de la raíz del sorgo (Sorghum bicolor (L.) Moench), Tesis M.S. Universidad de Puerto Rico, Mayagüez, P.R.

8. Chapman, R. A. and Turner, D. R., 1975. Effect of Meloidogyne incognita on reproduction of Pratylenchus penetrans in red clover and alfalfa, J. Nematol. 7(1): 6-10.

9. Christie, J. R. and Perry, V. G., 1951. Removing nematodes from soil, Proc. Helminth. Soc. Wash. 18: 106-108.

10. Fawcett, G. L., 1915. Fungus diseases of coffee in Puerto Rico, P.R. Agri. Exp. Stn. Bull. 17: 1-29. 
11. Gómez Tovar, J., 1972. Estudio preliminar del nemátodo nodulador del café (Meloidogyne exigua) y su control químico, Nematropica 2(1): 18.

12. Hanania, J. C., 1976. Evaluación de variedades y nematicidas-insecticidas contra $\mathrm{Me}$ loidogyne incognita en la habichuela soya (Glycine max (L.) Merr.). Tesis M.S. Univ. P.R., Mayagüez, P.R.

13. Inserra, R., O'Bannon, J. H., and Yuhl, W. A., 1974. System activity of Phenamiphos on control of Meloidogyne arenaria on Gardenia jasminoides, Nematropica 4(1): 2. (Abstr.)

14. Lordello, L. G. E., 1972. Nematode Pest of Coffee. In J. M. Webster, Ed, Economic Nematology. Academic Press, London, pp 268-284.

15. Miller, H. N., 1971. Comparison of nematicides and methods of application for the control of Meloidogyne incognita on gardenia, Nematropica I(I): 14. (Abstr.)

16. Miller, P. M. and Rich, S., 1974. Effect of soil temperature on control of Pratylenchus penetrans by three contact nematicides, Plant Dis. Rep. 58(8): 708-709.

17. Monterroso, D., 1973. Estudio de los nemátodos que atacanel café (Coffeae arabica L.), su distribución en Puerto Rico y algunas alternativas de de control, Tesis M.S. Univ. P.R., Mayagüez, P.R.

18. Pessoa, O., 1973. Estudio evaluativo de cuatro nematicidas sistémicos en el tratamiento de rizomas de banano (Musa acuminata (AAA). Tesis de grado I.A. Facultad de Agronomía. Univ. Costa Rica.

19. Román, J., Rivas, X. y Rodríguez, J., 1974. Control químico de los nemátodos del plátano, Nematropica 4(1): 5. (Abstr.)

20. Vicente-Chandler, J., Abruña, F., Bosque-Lugo, R. y Silva, S., 1969. El cultivo intensivo de café en Puerto Rico, Esta. Exp. Agri. Univ. P.R., Bol. 218. 